\title{
Pheochromocytoma multisystem crisis with transient stress cardiomyopathy due to ruptured pheochromocytoma
}

\author{
Kenji Sakamoto, Suano Kojima, Seiji Hokimoto, Hisao Ogawa
}

Department of Cardiovascular Medicine, Graduate School of Medical Sciences, Kumamoto University, Kumamoto, Japan

\section{Correspondence to} Dr Kenji Sakamoto, sakakenn@kumamoto-u.ac.jp

Accepted 12 November 2015

\section{DESCRIPTION}

A 64-year-old woman was transported to emergency room, with intense breast pain with impending shock. She had been diagnosed with mammary carcinoma, and pheochromocytoma was discovered during preoperative examinations. Reduced ejection fraction (EF; 30\%) with apical ballooning indicated acute coronary syndrome or Takotsubo cardiomyopathy, ${ }^{1}$ we inserted an intra-aortic balloon pump (IABP) after confirming intact coronary arteries via sequential coronary angiograms.

Seven hours after use of the IABP started, the sudden intense breast pain recurred, with mental confusion. Blood pressure (BP) increased to 190/ $110 \mathrm{~mm} \mathrm{Hg}$ with $160 \mathrm{bpm}$ tachycardia, so deep sedation and tracheal intubation were started as we suspected a pheochromocytoma multisystem crisis (PMC). ${ }^{2}$ Subsequently, BP decreased to $50 \mathrm{~mm} \mathrm{Hg}$ and $\mathrm{EF}$ was $8 \%$ (video 1), causing us to introduce percutaneous cardiopulmonary support. Careful administration of prazosin was initiated, titrated to

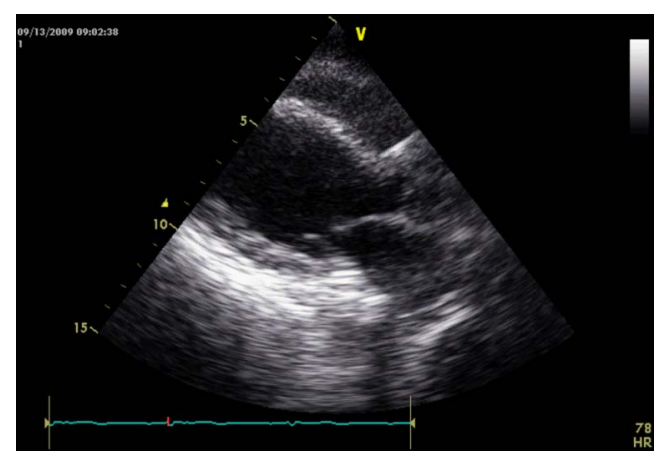

Video 1 Ejection fraction was reduced to $8 \%$ on cardiac echo several hours after intra-aortic balloon pump insertion. This finding made us decide to introduce additional support with percutaneous cardiopulmonary support.

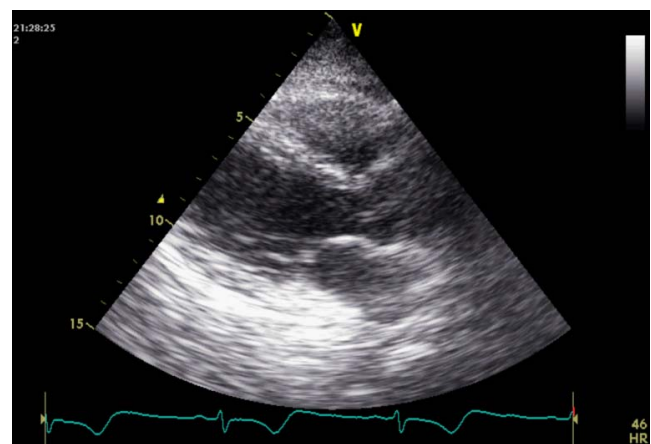

Video 2 Improved cardiac function on day 6.

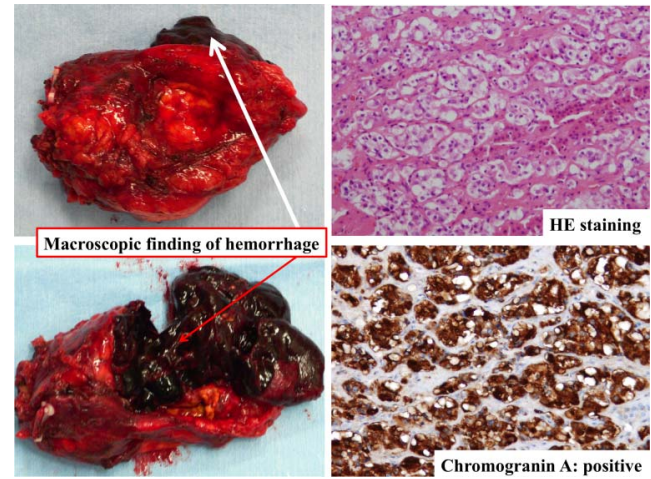

Figure 1 Macroscopic and microscopic tumour findings.

a dose of $5 \mathrm{mg}$ /day. Sufficient improvement of cardiac function on day 6 (video 2) allowed withdrawal of the mechanical devices. Complicated liver and kidney failure as well as disseminated intravascular coagulation improved with multidisciplinary treatment under continuous deep sedation to avoid recurrence. Laparoscopic adrenalectomy on day 16 and sequential breast cancer resection were completed without awakening the patient. Macroscopic bleeding in the adrenal gland was found by the surgeon.

Histopathologically, adrenomedullary cell-like cells with abundant granular cytoplasm proliferation with nest formation were observed among severe hemorrhagic necrosis. Intense immunoreactivity for CgA diagnosed pheochromocytoma (figure 1).

Although the precise trigger was unknown, ruptured pheochromocytoma caused PMC with stepwise cardiogenic shock due to severe transient cardiomyopathy.

\section{Learning points}

- Ruptured pheochromocytoma can cause pheochromocytoma multisystem crisis.

- Continuous sedation and aggressive prazosin administration allowed adrenalectomy without recurrent crisis.

- Immediate intervention is required after diagnosis of pheochromocytoma.

Acknowledgements The authors thank Floyd Hodgins for his review and editing advice. They also thank Koji Enomoto for data collection.

Competing interests None declared. 
Patient consent Obtained.

Provenance and peer review Not commissioned; externally peer reviewed.
2 Newell KA, Prinz RA, Pickleman J, et al. Pheochromocytoma multisystem crisis. A surgical emergency. Arch Surg 1988;123:956-9.

\section{REFERENCES}

1 Kurisu S, Sato H, Kawagoe T, et al. Tako-tsubo-like left ventricular dysfunction with ST-segment elevation: a novel cardiac syndrome mimicking acute myocardial infarction. Am Heart J 2002;143:448-55.

Copyright 2015 BMJ Publishing Group. All rights reserved. For permission to reuse any of this content visit http://group.bmj.com/group/rights-licensing/permissions.

BMJ Case Report Fellows may re-use this article for personal use and teaching without any further permission.

Become a Fellow of BMJ Case Reports today and you can:

- Submit as many cases as you like

- Enjoy fast sympathetic peer review and rapid publication of accepted articles

- Access all the published articles

- Re-use any of the published material for personal use and teaching without further permission

For information on Institutional Fellowships contact consortiasales@bmjgroup.com

Visit casereports.bmj.com for more articles like this and to become a Fellow 